\title{
Sorption and Transformation of Pyrantel Pamoate by Synthetic Birnessite
}

\author{
Tran Thai Ha ${ }^{1 *}$, Gallard Hervé2 ${ }^{2}$ Labanowski Jérôme ${ }^{2}$ \\ ${ }^{1}$ Ho Chi Minh City Open University, Ho Chi Minh City, Vietnam \\ ${ }^{2}$ Université de Poitiers, Poitiers, France
}

Received: 29 August 2017

Accepted: 16 October 2017

\begin{abstract}
Pyrantel pamoate is a combination of pyrantel and pamoate used as a deworming agent for domesticated animals. This study investigated the sorption and transformation of pyrantel pamoate by birnessite $\left(\boldsymbol{\delta}-\mathrm{MnO}_{2}\right)$ under different conditions. Pamoate was first oxidized into keto naphthalene derivatives by manganese oxide. The pamoate degradation rate obeyed the second-order kinetic law, first order with respect to $\mathrm{MnO}_{2}$ and first order with respect to pamoate. Pyrantel was not transformed by birnessite but showed adsorption on birnessite only after $20 \mathrm{~h}$ of reaction time when pamoate was transformed into products that could not participate in the solubilization of pamoate. The presence of natural organic matter showed inhibition of pamoate transformation and reduced pyrantel adsorption probably by competition for reactive sites and by enhancing water solubility of pyrantel. In soils and sediments, manganese oxide can participate in the oxidation of pamoate and sorption of pyrantel.
\end{abstract}

Keywords: birnessite, natural organic matter, reaction rate, sorption, transformation products

\section{Introduction}

Pyrantel pamoate is a combination of pyrantel (PYR) and pamoate (PMA) used as deworming agent in the treatment of hookworms and roundworms (Ascaris lumbricoides) in domesticated animals such as horses, cattle, sheep, pigs, cats, dogs, and many other species [1].

For example, in the UK, 3.78 tons of PYR PMA were reported to be used in the sheep industry in 2001 [1]. PYR PMA is introduced into the environment mainly through faeces, with $60 \%$ of ingested drug being excreted unchanged [2]. However, there is still a lack of information about the presence and fate of PYR PMA in

*e-mail: ha.tt@ou.edu.vn

the environment, the former postulated to be degraded at the thiophene moiety and/or pyrimidine function [2].

Pamoic acid, also called embonic acid, is a naphthoic acid derivative. In pharmacology, pamoate ion, the salt form of pamoic acid (pKa of 2.7), can be used as a counter ion to increase drug solubility in water by hydrogen bonding [3]. PMA is considered by the Food and Drug Administration as an inactive compound that enables long-acting formulations of drugs such as the anthelminthic oxantel PMA and PYR PMA, the psychoactive compounds hydroxyzine pamoate (Vistaril) and imipramine pamoate (Tofranil-PM); and the peptide hormones triptorelin pamoate (Trelstar) and octreotide pamoate (OncoLar) [4-7].

PMA was demonstrated in a recent study to have agonist activity for the orphan $\mathrm{G}$ protein-coupled receptor [8] - a large family of plasma membrane 
proteins that represent a major target for current therapeutic drugs and agents under development. PMA was also found to be an inhibitor of the DNA polymerase $\beta$, which plays a central role in repair of damaged DNA bases by base excision repair pathways [8]. These recent data suggest that its uses and inactive properties may be reexamined.

The abiotic transformation of the combination of a hydrophobic drug and organic salt complex molecule by oxide minerals such as manganese oxide is not known. Manganese oxides $\mathrm{MnO}_{2}$ are naturally present in soils and sediments and can contribute to the abiotic removal of micropollutants [9]. Currently, authors have proposed using $\mathrm{MnO}_{2}$ as geomedia for passive treatment of urban stormwater [10] and removal of phenolic compounds [11-13]. The transformation of organic compounds by manganese oxide occurs in two steps. First, the organic compound forms a surface complex precursor with manganese oxide [11, 14-15], and in the second step electron transfer leads to the release of dissolved manganese and transformation products [11, 14, 16]. These reactions could participate in the degradation of PYR PAM in soils contaminated by manure. PMA is susceptible to being degraded by manganese oxide because phenolic moieties readily reduced manganese oxide and are transformed into benzoquinones. Besides, the presence of natural organic matter (NOM) in the aqueous solution can significantly influence the transport of organic micropollutants [17-18]. In a recent study, organic carbon was reported to be trapped and stabilized by $\mathrm{MnO}_{2}$ through bridging and/or bidentate bond between carboxylate group of $\mathrm{NOM}$ and $\mathrm{MnO}_{2}$ mineral surface site [19].

The aim of this study was to investigate the adsorption and transformation reactions of pyrantel pamoate by manganese oxide birnessite for $\mathrm{pH}$ values between 4.0 and 6.0. The role of NOM was also evaluated. Transformation products were identified by LC-MS/MS in order to propose a reaction pathway for the transformation of PYR PAM by manganese oxide.

\section{Material and Methods}

\section{Manganese Dioxide and Reagents}

\section{Preparation of Manganese Dioxide and Characterization}

Manganese dioxide birnessite $\left(\delta-\mathrm{MnO}_{2}\right)$ was synthesized according to the method of Murray (1974) [20]. Eight mmoles of $\mathrm{KMnO}_{4}$ and 16 mmoles of $\mathrm{NaOH}$ were added in $3 \mathrm{~L}$ deionized water, followed by a dropwise addition of $1.5 \mathrm{~L} \mathrm{MnCl}$ solution (12 $\mathrm{mmol} \mathrm{L}^{-1}$ ). The resulting $\mathrm{MnO}_{2}$ particles were collected by decantation and the centrifugation, and the supernatant was replaced by deionized water several times until conductivity was significantly reduced.
The $\mathrm{MnO}_{2}$ stock suspension $\left(26 \mathrm{mmol} \mathrm{L}^{-1}\right)$ was stored at $4^{\circ} \mathrm{C}$ before use. No change in reactivity was observed during the entire duration of the study. The concentration of the $\mathrm{MnO}_{2}$ stock suspension was determined after reduction by ascorbic acid and analysis of $\mathrm{Mn}^{2+}$ by the formaldoxime spectrophotometric method [21]. The specific surface area determined by BET method using $\mathrm{N}_{2}$ as adsorbate was $218 \mathrm{~m}^{2} \mathrm{~g}^{-1}$.

The average oxidation number of $\mathrm{Mn}$ in the manganese dioxide was determined by the iodometric method [22]. The oxidation number was determined from sodium thiosulfate titration of iodine produced by the oxidation of iodide with a known amount of $\mathrm{MnO}_{2}$. The oxidation number of $\mathrm{Mn}$ in $\mathrm{MnO}_{2}$ was 3.66.

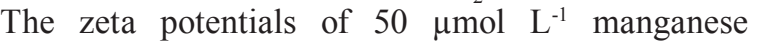
dioxide suspensions were determined at ionic strengths of $10 \mathrm{mmol} \mathrm{L}^{-1}$ and $1 \mathrm{mmol} \mathrm{L}^{-1} \mathrm{NaNO}_{3}$ for $\mathrm{pH}$ between 2.5 and 6.0. Measurements were performed with a Malvern Zetasizer. Results confirmed that manganese oxide particles were negatively charged between $\mathrm{pH} 3.0$ and 6.0 and that the $\mathrm{pH}_{\text {iep }}$ was below 2.5.

\section{Reagents}

PYR PAM and pamoic acid disodium salt were purchased from Sigma Aldrich (Saint Quentin-Fallavier, France). Stock and diluted solutions of pyrantel pamoate and PMA were prepared in ultra-pure water and were stored less than one month at $+4^{\circ} \mathrm{C}$ before use. Ultra-pure water was produced from a Milli-Q water purification system (Millipore).

Suwannee River NOM (SR-NOM) was purchased from the International Humic Substances Society (Minnesota, USA) and was used as received. The NOM stock solutions were prepared in ultra-pure water at $10 \mathrm{mgC} \mathrm{L}^{-1}$ and filtered through $0.45 \mu \mathrm{m}$ membrane filter before use. The solutions were stored at $+4^{\circ} \mathrm{C}$ and were diluted to $2 \mathrm{mgC} \mathrm{L}^{-1}$ and $0.5 \mathrm{mgC} \mathrm{L}^{-1}$ prior to use.

\section{Experimental Methods}

Experiments were conducted in $150 \mathrm{~mL}$ amber glass bottles equipped with Teflon caps. $\mathrm{MnO}_{2}$ suspensions $(100 \mathrm{~mL})$ were stirred on a magnetic stir plate $(480 \mathrm{rpm})$ at room temperature $\left(22 \pm 2^{\circ} \mathrm{C}\right)$ for $24 \mathrm{~h}$ before the reaction was initiated by adding a volume of the PYR PMA or PMA stock solution. The suspension was continuously stirred during the entire duration of the experiment.

Concentrations of $\mathrm{MnO}_{2}$ were 125, 250, 375, and $500 \mu \mathrm{mol} \mathrm{L}-1 \mathrm{MnO}_{2}$. The initial concentration of PMA was $260 \mathrm{nmol} \mathrm{L}^{-1}$. The $\mathrm{pH}$ was maintained constant \pm 0.1 at $\mathrm{pH} 4.0,4.5,5.0,5.5$, and 6.0 with $10 \mathrm{mmol} \mathrm{L}^{-1}$ acetate buffer.

For the experiments with NOM, suspensions containing both $\mathrm{MnO}_{2}$ and $\mathrm{NOM}$ were first equilibrated $24 \mathrm{~h}$ before pyrantel pamoate or PMA solution was added. The $\mathrm{pH}$ was controlled by adding manually $\mathrm{HCl}$ or $\mathrm{NaOH} 0.1 \mathrm{~mol} \mathrm{~L}^{-1}$ instead of using acetate buffer. 


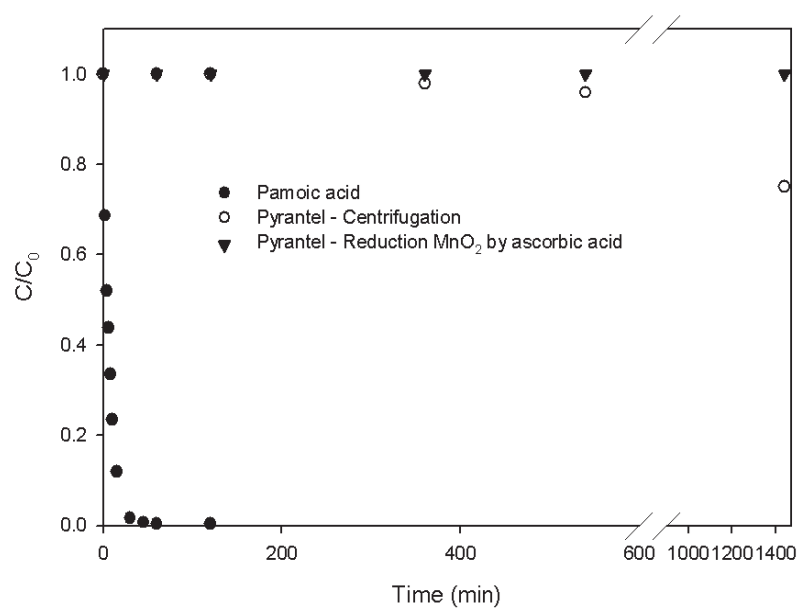

Fig. 1. Behaviour of pyrantel pamoate in the presence of birnessite $\left([\mathrm{MnO}]_{2}=500 \mu \mathrm{M},[\mathrm{PMA}]_{0}=260 \mathrm{nM},[\mathrm{PYR}]_{0}=260\right.$ $\mathrm{nM} 10 \mathrm{mM}$ acetate buffer $\mathrm{pH}$ 5.0).

Aliquots were collected at different time intervals to monitor the reaction time course. Two methods were used to quench the reaction before analysis: (i) $5 \mathrm{~mL}$ reaction aliquot was centrifuged at $10,000 \mathrm{rpm}$ for $20 \mathrm{~min}$ and $1 \mathrm{~mL}$ of the supernatant was transferred to separate $2 \mathrm{~mL}$ amber vial for HPLC analysis; (ii) $1 \mathrm{~mL}$ reaction aliquot was added to $2 \mathrm{~mL}$ HPLC amber vial containing $10 \mu \mathrm{L} 0.57 \mathrm{~mol} \mathrm{~L}^{-1}$ ascorbic acid, and the mixture was vortexed for $10 \mathrm{~s}$ to reduce manganese oxide. Centrifuging allowed us to determine PYR PMA present in the aqueous phase, whereas the reduction by ascorbic acid allowed us to determine PYR PMA and transformation products present in the aqueous phase and sorbed on $\mathrm{MnO}_{2}$. All samples were analysed within $24 \mathrm{~h}$.

\section{Analytical Methods}

The concentrations of PYR or PMA in the samples collected during the kinetic experiment were analysed

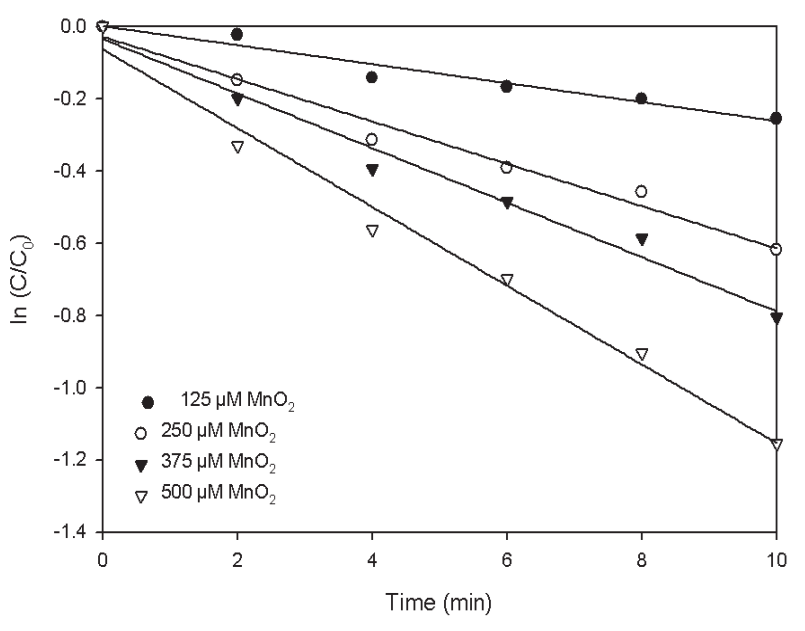

Fig. 2. Influence of initial concentrations of $\mathrm{MnO}_{2}$ on removal of PMA $\left([\mathrm{PMA}]_{0}=260 \mathrm{nM}, \mathrm{pH} 5.0,10 \mathrm{mM}\right.$ acetate buffer $)$.

by a HPLC system (Waters 2695 Separation module) coupled with a Waters 2489 UV/Visible detector. The absorbance detection wavelengths were set at $240 \mathrm{~nm}$ and $320 \mathrm{~nm}$ for PMA and PYR, respectively. The mobile phase consisted of $80 \% \mathrm{MeOH} / 20 \%$ acidified water with $0.1 \%$ formic acid. A Kinetex C18 column $(4.6 \times 250 \mathrm{~mm}, 5 \mu \mathrm{m})$ was used for separation

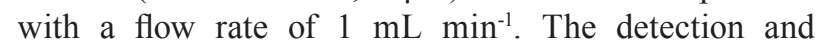
quantification limits of PMA were $9.0 \mathrm{nmol} \mathrm{\textrm {L } ^ { - 1 } \text { and }}$ $28.7 \mathrm{nmol} \mathrm{L}^{-1}$, respectively, and were determined from the standard deviation of 7 replicates of a 35 nmol L-1 PMA standard solution for an injection volume of $100 \mu \mathrm{L}$. Variation coefficients were below $5 \%$.

The identification of transformation products was performed by using a Thermo Scientific system (Villebon sur Yvette, France) equipped with a Thermo Scientific Q-Exactive Quadrupole-Orbitrap mass spectrometer equipped with a high resolution accuratemass Orbitrap detector, an Accela Open AutoSampler, and an Accela 1250 Pump. A flow-rate of $0.5 \mathrm{~mL} \mathrm{~min}^{-1}$ was used with a linear gradient from $10 \% \mathrm{MeOH} / 90 \%$

Table 1. Pseudo first-order kinetic rate constants for the transformation of PMA by $\mathrm{MnO}_{2}$ in $10 \mathrm{mmol} \mathrm{L}{ }^{-1}$ acetate buffer at $\mathrm{pH}$ 5.0.

\begin{tabular}{|c|c|c|c|c|}
\hline $\begin{array}{c}{[\mathrm{PMA}]_{0}} \\
\mathrm{nM}\end{array}$ & $\begin{array}{c}{\left[\mathrm{MnO}_{2}\right]_{0}} \\
\mu \mathrm{M}\end{array}$ & $\mathrm{pH}$ & $\begin{array}{c}\mathrm{k}_{\text {obs }} \\
\mathrm{min}^{-1}\end{array}$ & $\begin{array}{c}\text { Model fit } \\
\left(\mathrm{R}^{2}\right)\end{array}$ \\
\hline 260 & 125 & $5.0 \pm 0.1$ & $0.026 \pm 0.003$ & 0.99 \\
\hline 260 & 250 & $5.0 \pm 0.1$ & $0.059 \pm 0.004$ & 0.99 \\
\hline 260 & 375 & $5.0 \pm 0.1$ & $0.076 \pm 0.005$ & 0.99 \\
\hline 260 & 500 & $5.0 \pm 0.1$ & $0.109 \pm 0.006$ & 0.99 \\
\hline 260 & 125 & $4.0 \pm 0.1$ & $0.180 \pm 0.006$ & 0.99 \\
\hline 260 & 125 & $4.5 \pm 0.1$ & $0.073 \pm 0.001$ & 0.99 \\
\hline 260 & 125 & $5.0 \pm 0.1$ & $0.030 \pm 0.005$ & 0.98 \\
\hline 260 & 125 & $5.5 \pm 0.1$ & $0.02 \pm 0.001$ & 0.93 \\
\hline 260 & 125 & $6.0 \pm 0.1$ & $0.008 \pm 0.001$ & \multicolumn{2}{|c|}{0.93} \\
\hline
\end{tabular}




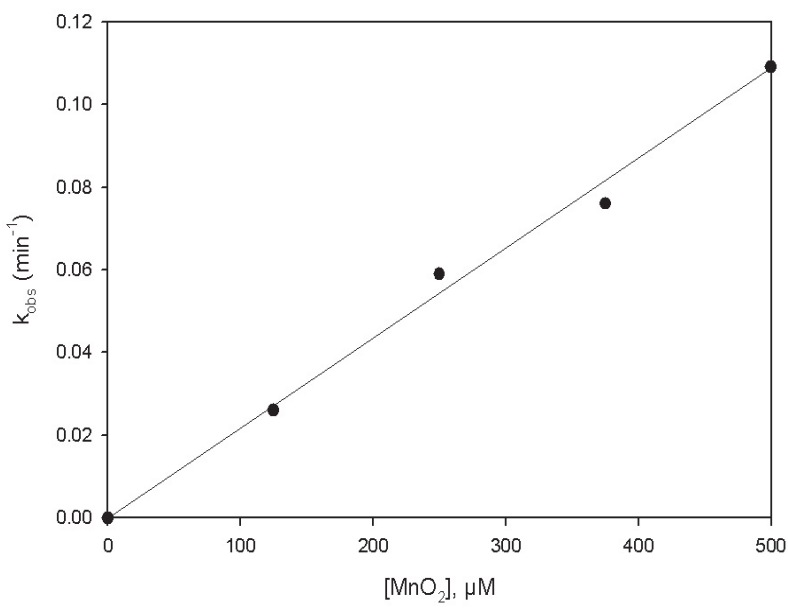

Fig. 3. First-order dependence with respect to $\mathrm{MnO}_{2}$.

acidified water $(0.1 \% \mathrm{v} / \mathrm{v}$ formic acid $)$ to $100 \% \mathrm{MeOH}$ in $20 \mathrm{~min}, 100 \%$ of $\mathrm{MeOH}$ was kept $15 \mathrm{~min}$ and then back to initial conditions in $5 \mathrm{~min}$. The electrospray ionization was performed in both positive and negative modes. A mass range TIC of 50-600 amu was applied. An ion transfer capillary temperature of $350^{\circ} \mathrm{C}$ and a spray voltage of $4.5 \mathrm{kV}$ were used. The MS/MS analyses were carried out with normalized collision energy between 25 and $40 \%$. The activation time was $30 \mathrm{~ms}$, the $\mathrm{Q}$ activation parameter was set at 0.25 , and the isolation width was 2 amu.

\section{Results and Discussion}

\section{Preliminary Study}

In the absence of $\mathrm{MnO}_{2}$, no appreciable amount of PYR PMA was removed within $80 \mathrm{~h}$. In the presence of $500 \mu \mathrm{mol} \mathrm{L}{ }^{-1}$ birnessite at $\mathrm{pH}$ 5.0, PMA was rapidly eliminated for the first hour whereas PYR remained in solution (Fig. 1). PYR was not degraded by birnessite because the concentration of PYR determined after reduction of $\mathrm{MnO}_{2}$ by ascorbic acid remained constant and equal to the initial concentration of PYR. PYR was only sorbed onto $\mathrm{MnO}_{2}$ after 1,400 min because the concentration of PYR determined after centrifugation decreased significantly.

\section{Transformation Kinetics of PMA by $\mathrm{MnO}_{2}$}

Transformation kinetics of PMA were studied at $\mathrm{pH}$ 5.0 using a pure solution of PMA (i.e., in the absence of PYR). The rate of PMA could be well described by pseudo first-order kinetics as shown in Fig. 2 for $\mathrm{MnO}_{2}$ concentrations of $125,250,375$, and $500 \mu \mathrm{mol} \mathrm{L} \mathrm{L}^{-1}$ and $[\mathrm{PMA}]_{\mathrm{o}}=260 \mathrm{nmol} \mathrm{L}^{-1}$.

Pseudo first-order rate constants $\mathrm{k}_{\mathrm{obs}}$ were determined according to Equation 1 for all initial $\mathrm{MnO}_{2}$ concentrations. Values of $\mathrm{k}_{\text {obs }}$ are given in Table 1.

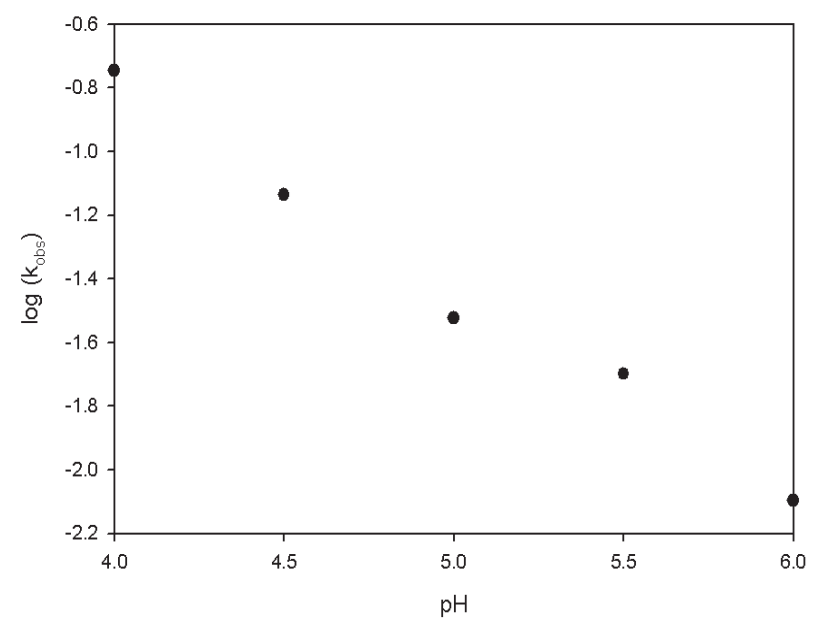

Fig. 4. Dependence of $\mathrm{k}_{\mathrm{obs}}$ with respect to $\mathrm{H}^{+}$concentrations.

$$
\frac{d[P M A]}{d t}=-k_{o b s} \cdot[P M A]
$$

The $\mathrm{k}_{\mathrm{obs}}$ values increased from 0.026 to $0.109 \mathrm{~min}^{-1}$ when $\mathrm{MnO}_{2}$ concentrations varied from $125 \mu \mathrm{mol} \mathrm{L}^{-1}$ to $500 \mu \mathrm{mol} \mathrm{L}^{-1}$ at pH 5.0 (Table 1).

Fig. 3 shows that $\mathrm{k}_{\text {obs }}$ increased linearly with $\mathrm{MnO}_{2}$ concentration indicating that kinetic is first-order with respect to $\mathrm{MnO}_{2}$. The transformation of PMA by $\mathrm{MnO}_{2}$ is then a second-order rate law, first-order with respect to PMA and first-order with respect to $\mathrm{MnO}_{2}$ (Equation 2).

$$
\frac{d[P M A]}{d t}=-k_{o b s} \cdot[P M A]=-k_{p H 5} .[P M A] \cdot\left[\mathrm{MnO}_{2}\right]
$$

Then second-order rate constant $\mathrm{k}_{\mathrm{pH} 5}=(3.6 \pm 0.24)$ $\mathrm{L} \mathrm{mol}{ }^{-1} \mathrm{~s}^{-1}$ was calculated as the slope of the linear curve in Fig. 3. In previous study on phenolic compounds

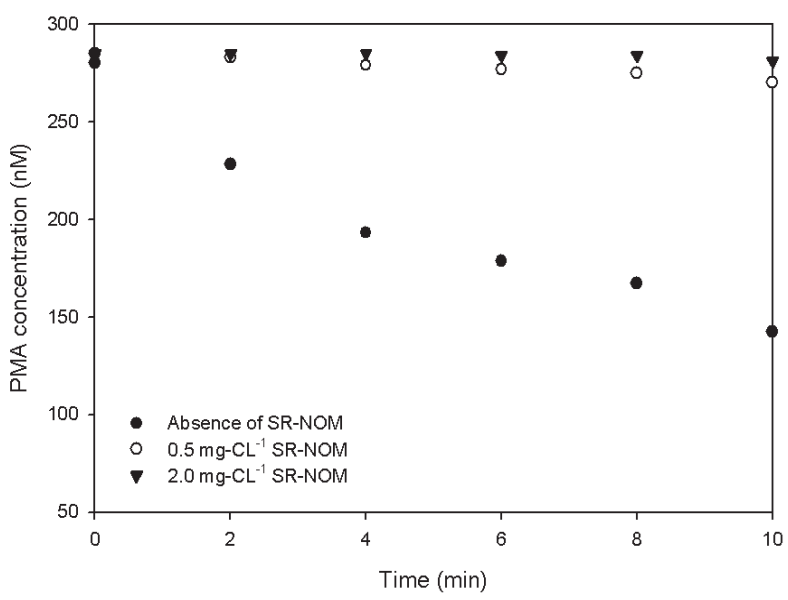

Fig. 5. Effect of SR-NOM on oxidation of PMA by $\mathrm{MnO}_{2}$ $\left([\mathrm{PMA}]_{0}=260 \mathrm{nM}\right.$ and $\left.\left[\mathrm{MnO}_{2}\right]_{0}=125 \mu \mathrm{M}\right)$. 
Table 2. MS spectra of PMA and its transformation product.

\begin{tabular}{|c|c|c|c|c|c|c|c|}
\hline Name & $\begin{array}{c}\text { Molecular } \\
\text { formula }\end{array}$ & $\begin{array}{c}\text { Theorical m/z } \\
{[\mathrm{M}-\mathrm{H}]^{-}}\end{array}$ & $\begin{array}{c}\text { Experimental m/z } \\
{[\mathrm{M}-\mathrm{H}]^{-}}\end{array}$ & Delta ppm & MS & $\begin{array}{l}\text { Retention } \\
\text { time }\end{array}$ & Proposed chemical structure \\
\hline PMA & $\mathrm{C}_{23} \mathrm{H}_{16} \mathrm{O}_{6}$ & 387.0872 & 387.0874 & -0.546 & $\begin{array}{c}387(100) \\
388(30)\end{array}$ & 19.22 & \\
\hline A1 & $\mathrm{C}_{23} \mathrm{H}_{14} \mathrm{O}_{6}$ & 385.0707 & 385.0723 & 1.635 & $385(100)$ & 18.93 & \\
\hline A2 & $\mathrm{C}_{12} \mathrm{H}_{10} \mathrm{O}_{4}$ & 217.0495 & 217.0501 & 0.565 & $217(100)$ & 15.05 & \\
\hline A3 & $\mathrm{C}_{12} \mathrm{H}_{8} \mathrm{O}_{4}$ & 215.0339 & 215.0344 & 0.515 & $215(100)$ & 15.56 & \\
\hline
\end{tabular}

transformation by $\mathrm{MnO}_{2}$, second order rate constants ranged from $4.9 \times 10^{-3}$ for resorcinol to $30 \mathrm{~L} \mathrm{~mol}^{-1} \mathrm{~s}^{-1}$ for 3-methoxycatechol [14]. Value obtained for PMA is close to $2.33 \mathrm{~L} \mathrm{~mol}^{-1} \mathrm{~s}^{-1}$ for hydroquinone.

The effect of $\mathrm{pH}$ on the transformation of PMA by $\mathrm{MnO}_{2}$ was also investigated. The values given in Table 1 show that the $\mathrm{k}_{\text {obs }}$ values decreased from 0.180 to $0.008 \mathrm{~min}^{-1}$ when $\mathrm{pH}$ changed from 4.0 to 6.0 for $125 \mu \mathrm{mol} \mathrm{L}^{-1} \mathrm{MnO}_{2}$ suspension. The $\mathrm{k}_{\mathrm{obs}}$ values were plotted as a function of $\left[\mathrm{H}^{+}\right]$in Fig. 4, and the order of reaction with respect to $\left[\mathrm{H}^{+}\right]$was determined as $\mathrm{m}=0.75$.

The rate of PMA removal is then given by equation:

$$
\frac{d[P M A]}{d t}=-k \cdot\left[H^{+}\right]^{m} \cdot[P M A] \cdot\left[M n O_{2}\right]=-k_{o b s} \cdot[P M A]
$$

...with:

$$
k_{o b s}=k \cdot\left[H^{+}\right]^{m} \cdot\left[\mathrm{MnO}_{2}\right]
$$

Rate constant $\mathrm{k}$ was calculated equal to $(2.8 \pm 0.6) \mathrm{x}$ $10^{4} \mathrm{~L}^{1.75} \mathrm{~mol}^{-1.75} \mathrm{~s}^{-1}$.

The presence of SR-NOM strongly inhibited the degradation of PMA for $125 \mu \mathrm{mol} \mathrm{L}-1 \mathrm{MnO}_{2}$ (Fig. 5). Almost no transformation of PMA was observed for 0.5 and $2.0 \mathrm{mgC} \mathrm{L}^{-1}$ of NOM.

\section{Identification of Transformation Products of PMA}

Three transformation products, named A1, $\mathrm{A} 2$, and $\mathrm{A} 3$, were identified by LC-MS/MS for the transformation of PMA by $\mathrm{MnO}_{2}$ in the absence of PYR. Molecular formula, theoretical and experimental $\mathrm{m} / \mathrm{z}$, and proposed chemical structures of the 3 products are shown in Table 2.

Product A1 with m/z 385.07 differs from PMA by only 2 amu (Fig. 6). Then, A1 was postulated to be the oxidation product of naphtol rings by $\mathrm{MnO}_{2}$. Similar oxidation of phenolic compounds into keto products by $\mathrm{MnO}_{2}$ has been well documented [11, 23-25].

Product A2 has an experimental $\mathrm{m} / \mathrm{z}$ of 217.05 corresponding to molecular formula $\mathrm{C}_{12} \mathrm{H}_{10} \mathrm{O}_{4}$. The MS2 spectrum shows daughter ions with $\mathrm{m} / \mathrm{z} 173.06$ and 155.05 corresponding respectively to losses of $-\mathrm{CO}_{2}$ and $-\mathrm{H}_{2} \mathrm{O}$ (Fig. 7). Product A2 was postulated to be formed by the oxidative cleavage of the $\mathrm{C}-\mathrm{C}$ bond between the two naphthalene rings. This cleavage would be facilitated by electron delocalization due to the presence of the naphtyl rings and the two carbonyl functional groups. The MS2 spectrum of A3 presented in Fig. 8 shows ion fragments with mass losses of $-\mathrm{CO}_{2}$ and - $\mathrm{CO}$ consistent with the presence of carboxylic acid and carbonyl functional groups. The oxidation of the hydroxyl functional group in product A2 would give the product A3. A reaction pathway of PMA degradation by $\mathrm{MnO}_{2}$ is proposed in Fig. 9.

\section{Sorption of PYR onto $\mathrm{MnO}_{2}$ and Effect of NOM}

The pyrantel molecule could not be purchased alone. Thus, PYR sorption could only be studied in the presence of PMA. Fig. 10 presents new evidence of 
PYR sorption and the absence of degradation for one mmol L-1 $\mathrm{MnO}_{2}$ and approximately $300 \mathrm{nmol} \mathrm{L}^{-1}$ of PYR PMA at $\mathrm{pH}$ 5.0. Sorption of $50 \%$ PYR only took place after 24 hours of mixing. The absence of sorption for the first hours could be attributed to the presence of PMA and transformation products that increase the solubility of PYR. PYR was adsorbed onto $\mathrm{MnO}_{2}$ only when transformation products of PMA have lost their properties to form hydrogen bonds with PYR.

Fig. 11 shows the sorption isotherm of PYR obtained for different concentrations of $\mathrm{MnO}_{2}$ at $\mathrm{pH} 5.0$ for a contact time of 24 hours. Results could be well fitted by a Langmuir isotherm. The equilibrium constant $\mathrm{K}_{\text {ads }}$ was equal to $10.8 \pm 2.9 \mathrm{~L} \mathrm{mg}^{-1}$ and the adsorption capacity was $396.8 \pm 38.1 \mathrm{mg} \mathrm{kg}^{-1}$.

The effect of SR-NOM on sorption of PYR was studied for $1 \mathrm{mmol} \mathrm{L}^{-1} \mathrm{MnO}_{2}$ at $\mathrm{pH}$ 5. Results in Fig. 12 shows the evolution of sorbed PYR as a function of time in the absence and presence of $0.5 \mathrm{mgC} \mathrm{L}^{-1}$ SR-NOM. In the absence of NOM, sorption equilibrium was only reached after $24 \mathrm{~h}$ when PMA and products of PMA could not increase the solubility of PYR. In the presence of NOM, a significant amount of PYR was sorbed for the first hours. Equilibrium was also reached after 24 hours, but the amount of PYR sorbed was significantly lower than in the absence of NOM. The higher sorption

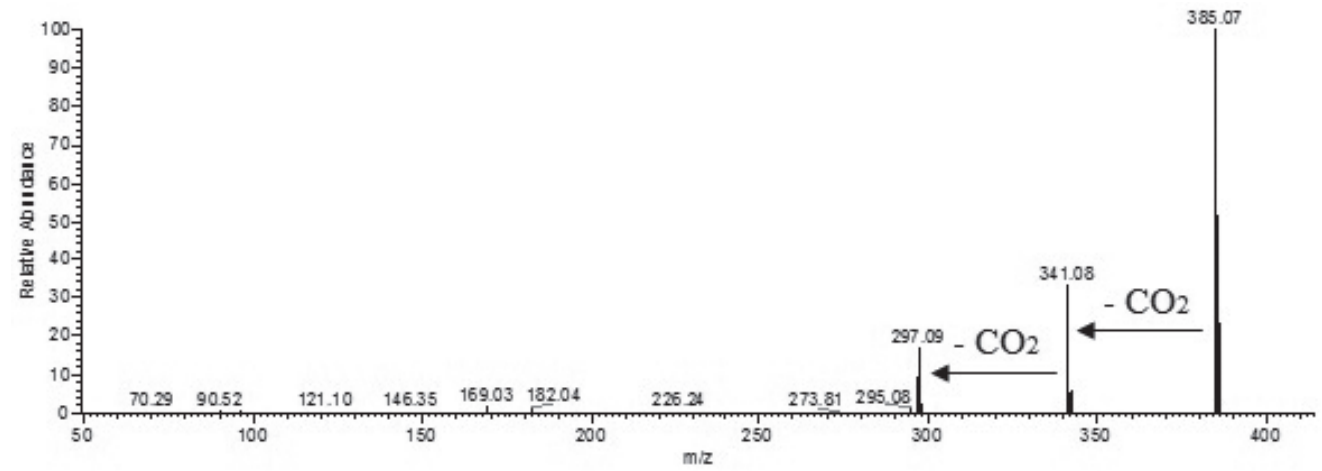

Fig. 6. MS2 spectra of product A1 produced from degradation of PMA by $\mathrm{MnO}_{2}$.

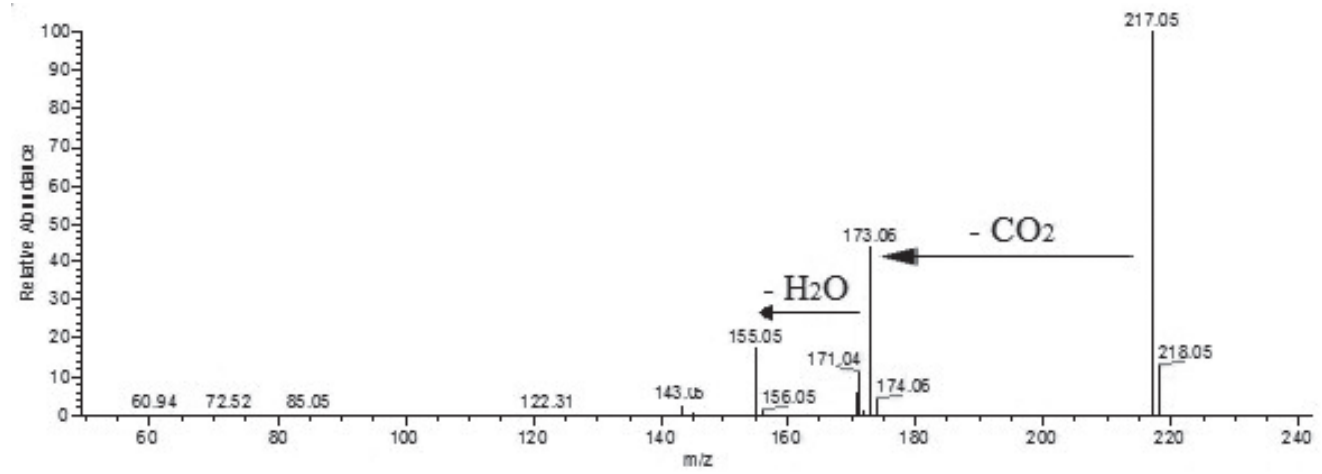

Fig. 7. MS2 spectra of product A2 produced from PMA degradation by $\mathrm{MnO}_{2}$.

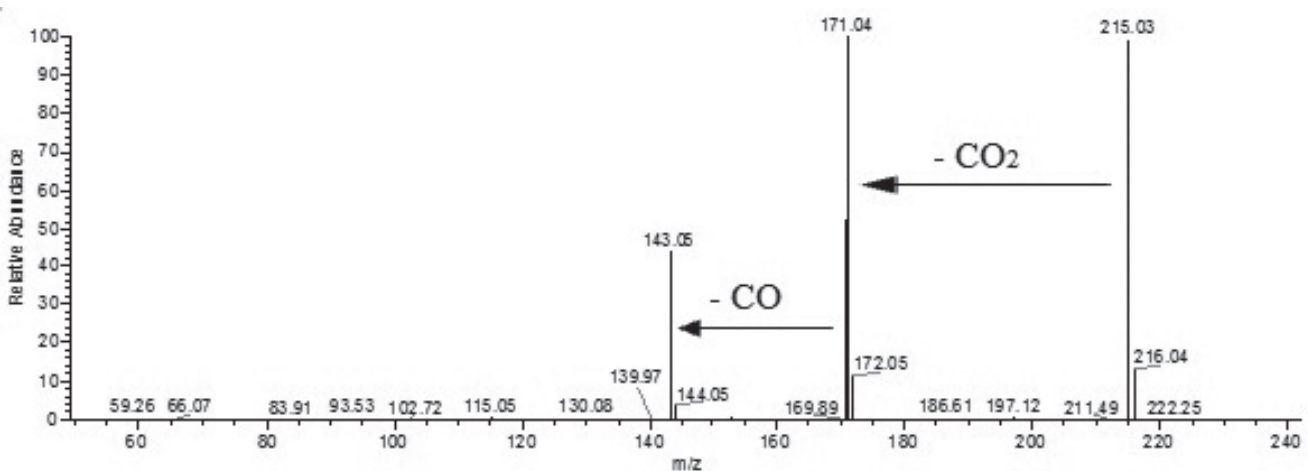

Fig. 8. MS2 spectra of product A3 produced from PMA degradation by $\mathrm{MnO}_{2}$. 
of PYR PMA in the presence of NOM for the first hours could be attributed to hydrophobic interactions and hydrogen bonding between PYR and NOM sorbed onto the surface of $\mathrm{MnO}_{2}$ [26]. Dissolved organic carbon measurement showed that adsorption of NOM was limited to $90 \mu \mathrm{gC} / \mathrm{mgMnO}_{2}$ and most NOM remained in
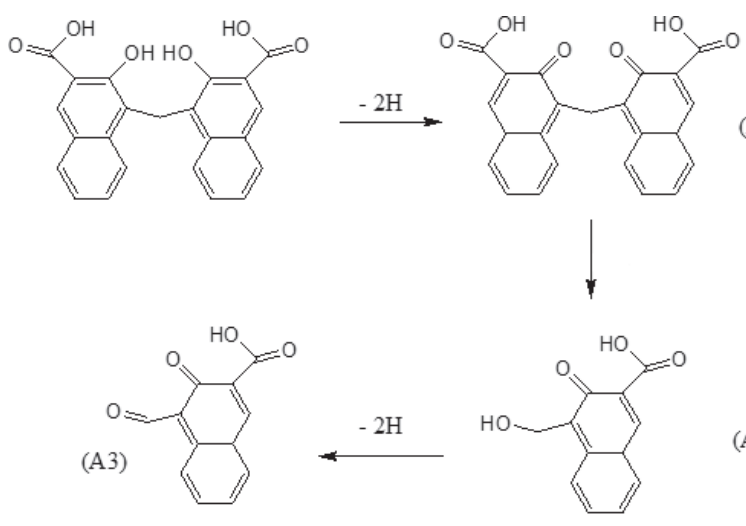

Fig. 9. Proposed reaction pathway for the degradation of PMA by $\mathrm{MnO}_{2}$.

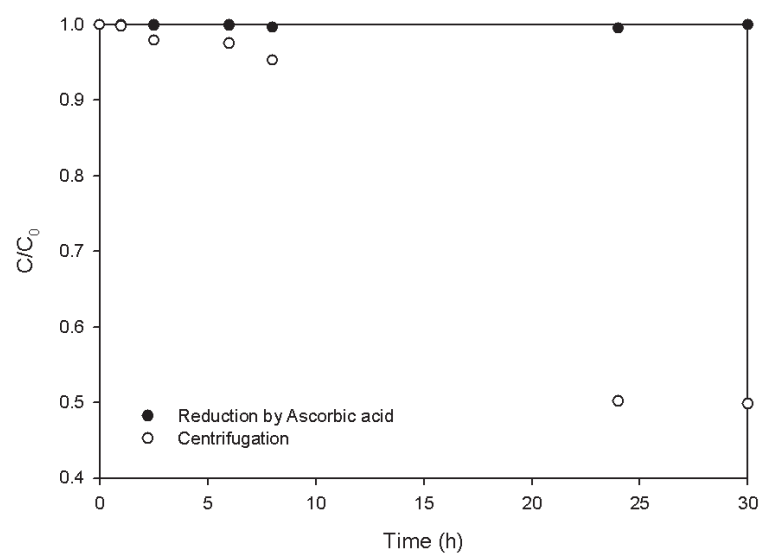

Fig. 10. Concentration profile of PYR in the presence of $\mathrm{MnO}_{2}$ after quenching by ascorbic acid or centrifuging $\left.\left(\left[\mathrm{MnO}_{2}\right]_{0}=1 \mathrm{mM} ; \mathrm{pH} \text {; [PYR-PMA }\right]_{0}=300 \mathrm{nM}\right)$.

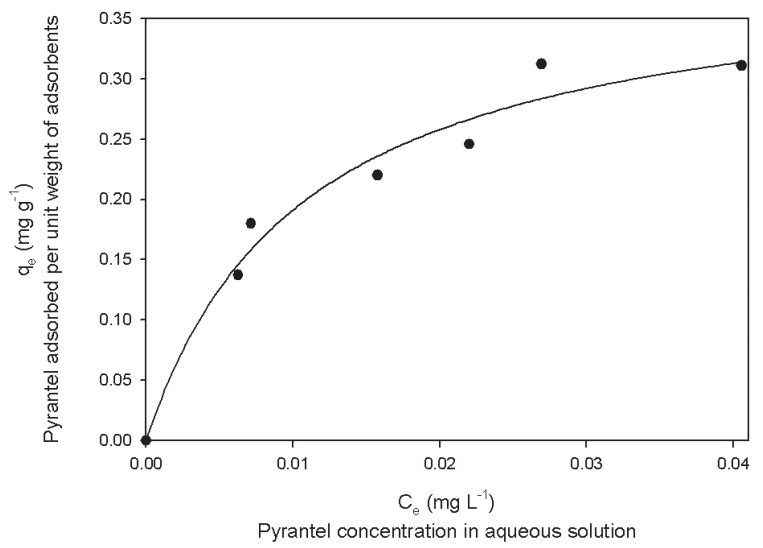

Fig. 11. Sorption isotherm of PYR by $\mathrm{MnO}_{2}$ at $\mathrm{pH}$ 5.0.

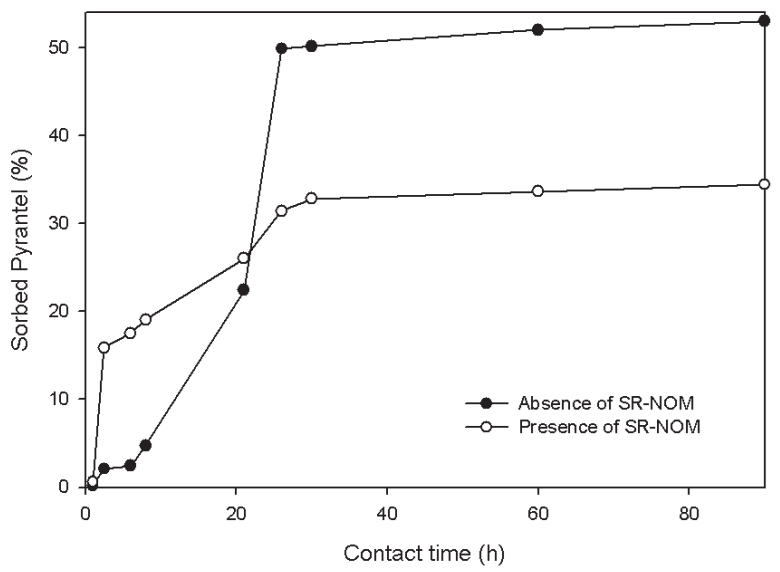

Fig. 12. Effect of NOM on sorption kinetic of PYR by $\mathrm{MnO}_{2}$ $\left(\left[\mathrm{MnO}_{2}\right]_{0}=1 \mathrm{mM}, \mathrm{pH} 5.0,[\mathrm{NOM}]_{0}=0.5 \mathrm{mgC} \mathrm{L}^{-1}\right)$.

solution. Sorption of NOM onto birnessite was low at $\mathrm{pH}$ 5.0 because both NOM and the surface of birnessite are negatively charged [27]. Thus, the presence of NOM in solution could also contribute to increasing the solubility of PYR by the formation of hydrogen bonds.

\section{Conclusion}

This study demonstrated that PYR PMA reacts with birnessite. PMA was first oxidized and hydrolysed into keto naphthalene derivatives by manganese oxide. The PMA degradation rate obeyed second-order kinetic law, and first-order with respect to $\mathrm{MnO}_{2}$ and PMA. The apparent second-order rate constant at $\mathrm{pH} 5.0$ is 3.6 $( \pm 0.24) \mathrm{L} \mathrm{mol}^{-1} \mathrm{~s}^{-1}$. The rate constants increased when $\mathrm{pH}$ decreased and the presence of NOM strongly inhibited PMA transformation due to competition for active sites.

PYR showed distinct behaviour with only sorption onto the surface of $\mathrm{MnO}_{2}$. During the first hours, PMA and transformation products of PMA solubilized PYR, which was not adsorbed by birnessite. A significant amount of PYR was adsorbed on birnessite after $20 \mathrm{~h}$ of reaction time when transformation products of PMA lost their properties to solubilize PYR. The presence of NOM adsorbed on the surface of birnessite could participate to the sorption of PYR PMA, but NOM in solution would also increase the solubility of PYR, which would explain the lower sorption at the equilibrium.

This study illustrates that interactions between organic compounds strongly influence the transformation and adsorption of micropollutants by metal oxides. Natural organic matter in soils and sediments can compete for reactive sites reducing transformation rates and adsorption capacity. However, NOM adsorbed on the surface of metal oxides can participate to the sorption of micropollutants, but can also increase the solubility of hydrophobic micropollutants. 


\section{Acknowledgements}

Tran Thai Ha thanks the Vietnamese government for financial support under a Vietnam-France grant for scientific research within the USTH program.

\section{References}

1. BOXALL A.B.A. Veterinary Medicines and the Environment. In Comparative and Veterinary Pharmacology - Handbook of Experimental Pharmacology; Cunningham F., Elliott J., Lees P., Eds., Springer: Berlin, Heidelberg, Germany, 199, 291, 2010.

2. HORVAT A.J.M., BABIC S., PAVLOVIC D.M., ASPERGER D., PELKO S., KASTELAN-MACAN M.. Analysis, occurrence and fate of anthelmintics and their transformation products in the environment. Trac-Trends in Analytical Chemistry, 31, 61, 2012.

3. SAESMAA T., TOTTERMAN A. Dissolution Studies on Ampicillin Embonate and Amoxycillin Embonate. Journal of Pharmaceutical and Biomedical Analysis, 8, 61, 1990.

4. LV C., LI J., HOU Z., LI M. Construction of Two New Metal-Organic Frameworks from Pamoic Acid and N-Containing Auxiliary Ligands. Journal of Inorganic and Organometallic Polymers and Materials, 24, 388, 2014.

5. CAO T., PENG Y., LIU T., WANG S., DOU J., LI Y., ZHOU C., LI D., BAI J. Assembly of a series of d(10) coordination polymers of pamoic acid through a mixed-ligand synthetic strategy: syntheses, structures and fluorescence properties. Crystengcomm, 16, 10658, 2014.

6. ZHANG L.N., SUN X.L., DU C.X., HOU H.W. Structural diversity and fluorescent properties of new metal-organic frameworks constructed from pamoic acid and different N-donor ligands. Polyhedron, 72, 90, 2014.

7. ZHAO P., SHARIR H., KAPUR A., COWAN A., GELLER E.B., ADLER M.W., SELTZMAN H.H., REGGIO P.H., HEYNEN-GENEL S., SAUER M., CHUNG T.D., BAI Y., CHEN W., CARON M.G., BARK L.S., ABOOD M.E. Targeting of the Orphan Receptor GPR35 by Pamoic Acid: A Potent Activator of Extracellular Signal-Regulated Kinase and beta-Arrestin2 with Antinociceptive Activity. Molecular Phamacology, 78, 560, 2010.

8. HU H.Y., HORTON J.K., GRYK M.R., PRASAD R., NARON J.M., SUN D.A., HECHT S.M., WILSON S.H., MULLEN G.P. Identification of small molecule synthetic inhibitors of DNA polymerase beta by NMR chemical shift mapping. Journal of Biological Chemistry, 279, 39736, 2004.

9. REMUCAL C.K., GINDER-VOGEL M. A critical review of the reactivity of manganese oxides with organic contaminants. Environmental Science: Process \& Impacts, 16, 1247, 2014.

10. GREBEL J.E., CHARBONNET J.A., SEDLAK D.L. Oxidation of organic contaminants by manganese oxide geomedia for passive urban stormwater treatment systems. Water Research, 88, 481, 2016.

11. STONE A. Reductive Dissolution of Manganese(II/IV) Oxides by Substituted Phenols. Environmental Science \& Technology, 21, 979, 1987.
12. LIN K., LIU W., GAN J. Oxidative Removal of Bisphenol A by Manganese Dioxide: Efficacy, Products, and Pathways. Environmental Science \& Technology, 43, 3860, 2009.

13. PARIDA K.M., PRADHAN A.C. Removal of phenolic compounds from aqueous solutions by adsorption onto manganese nodule leached residue. Journal of Hazardous Materials, 173, 758, 2010.

14. STONE A., MORGAN J. Reduction and Dissolution of Manganese(III) and Manganese(IV) Oxides by Organics. 1. Reaction with Hydroquinone. Environmental Science \& Technology, 18, 450, 1984.

15. BALGOOYEN S., ALAIMO P. J., REMUCAL C. K., GINDER-VOGEL M. Structural Transformation of $\mathrm{MnO}_{2}$ during the Oxidation of Bisphenol A. Environmental Science \& Technology, 51, 6053, 2017.

16. JIANG J., GAO Y., PANG S.Y., LU X.T., ZHOU Y., MA J., WANG Q. Understanding the Role of Manganese Dioxide in the Oxidation of Phenolic Compounds by Aqueous Permanganate. Environmental Science \& Technology, 49, 520, 2015.

17. CHEN W.R., DING Y., JOHNSON C.T., TEPPEN B.J., BOYD S.A., LI H. Reaction of Lincosamide Antibiotics with Manganese Oxide in Aqueous Solution. Environmental Science Technology, 44, 4486, 2010.

18. FEITOZA-FELIZZOLA J., HANNA K., CHIRON S. Adsorption and transformation of selected humanused macrolide antibacterial agents with iron(III) and manganese(IV) oxides. Environmental Pollution, 157, $1317,2009$.

19. JOHNSON K., PURVIS G., LOPEZ-CAPEL E., PEACOCK C., GRAY N., WAGNER T., MARZ C., BOWEN L., OJEDA J., FINLAY N., ROBERTSON S., WORRALL F., GREENWELL C. Towards a mechanistic understanding of carbon stabilization in manganese oxides. Nature Communications, 6, ncomms $8628,2015$.

20. MURRAY J. Surface Chemistry of Hydrous ManganeseDioxide. Journal of Colloid and Interface Science, 46, 357, 1974.

21. MORGAN J., STUMM W. Colloid-Chemical Properties of Manganese Dioxide. Journal of Colloid Science, 19, 347, 1964.

22. CHING S., LANDRIGAN J.A., JORGENSEN M.L. SolGel Synthesis of Birnessite from $\mathrm{KMnO}_{4}$ and Simple Sugars. Chemistry of Materials, 7, 1604, 1995.

23. HUGUET M., SIMON V., GALLARD H. Transformation of paracetamol into 1,4-benzoquinone by a manganese oxide bed filter. Journal of Hazardous Materials, 271, 245, 2014.

24. HUGUET M., DEBORDE M., PAPOT S., GALLARD H. Oxidative decarboxylation of diclofenac by manganese oxide bed filter. Water Research, 47, 5400, 2013.

25. ZHANG H.C., HUANG C.H. Oxidative transformation of triclosan and chlorophene by manganese oxides. Environmental Science \& Technology, 37, 2421, 2003.

26. MEANS J., WIJAYARATNE R. Role of Natural Colloids in the Transport of Hydrophobic Pollutants. Science, 215, 968, 1982.

27. ALLARD S., GUTIERREZ L., FONTAINE C., CROUE J.-P., GALLARD H. Organic matter interactions with natural manganese oxide and synthetic birnessite. Science of The Total Environment, 583, 487, 2017. 